\title{
Changes of Forest Stands Vulnerability to Future Wind Damage Resulting from Different Management Methods
}

\author{
O. Panferov ${ }^{*}$, , A. Sogachev ${ }^{2}$ and B. Ahrends ${ }^{3}$ \\ ${ }^{I}$ Georg-August-University, Bioclimatology, Büsgenweg 2, D-37077 Göttingen, Germany \\ ${ }^{2}$ Wind Energy Department, Risø National Laboratory for Sustainable Energy, TU of Denmark, Roskilde, Denmark \\ ${ }^{3}$ Georg-August-University, Soil Science of Temperate and Boreal Ecosystems, Büsgenweg 2, D-37077 Göttingen, \\ Germany
}

\begin{abstract}
The structure of forests stands changes continuously as a result of forest growth and both natural and anthropogenic disturbances like windthrow or management activities - planting/cutting of trees. These structure changes can stabilize or destabilize forest stands in terms of their resistance to wind damage. The driving force behind the damage is the climate, but the magnitude and sign of resulting effect depend on tree species, management method and soil conditions. The projected increasing frequency of weather extremes in the whole and severe storms in particular might produce wide area damage in European forest ecosystems during the $21^{\text {st }}$ century. To assess the possible wind damage and stabilization/destabilization effects of forest management a number of numeric experiments are carried out for the region of Solling, Germany. The coupled small-scale process-based model combining Brook90 [1] and SCAlar DIStribuiton turbulence model [2-4] is implemented. The SRES climate scenarios A1B and B1 dynamically downscaled by Climate Local Model CLM [5] are used to project the future climate conditions in the area. The experiments are performed for two tree species (spruce and beech) and a mixed stand and for two target diameter harvesting scenarios. The results show considerable increment of wind damage risks towards 2100 compared to "present climate conditions", caused by the combination of weak increase of wind speed and precipitation and strong increase of air and soil temperature. The effect is stronger for coniferous species than for deciduous ones. It is shown that management activities have a strong destabilizing effect on forests due to joint influence of climatic factors and decrease of stand density.
\end{abstract}

Keywords: Wind damage, target diameter harvesting, climate change, SCADIS, Brook90, coupled model.

\section{INTRODUCTION}

The structure of forests stands changes continuously as a result of forest growth or abruptly due to both natural and anthropogenic disturbances like windthrow or stem break or forest management activities - planting/cutting of trees. These structure changes can stabilize or destabilize forest stands in terms of their resistance to wind damage and increase or decrease the wind load on trees in a forest. The result would be the higher or lower probability of subsequent wind damage $[6,7]$.

By evaluating the consequences of natural impacts on forest structure [8] found out that after a windthrow or clearcut the risks increase strongly for the remaining stand around the gap. The studies of $[6,9]$ showed that any kind of forest thinning or harvesting results in instant destabilizing of remaining stand. In present study the attempt is made to consider the changes in climatic factors other than wind speed and soil temperature and to assess the long-term consequences of forest management activities. One of the standard silvicultural methods is the uneven-aged natural regeneration through selective thinning, which is assumed to

*Address correspondence to this author at the Georg-August-University, Bioclimatology, Büsgenweg 2, D-37077 Göttingen, Germany; Tel: +49 55I39121.15; E-mail: opanfyo@gwdg.de yield important ecological benefits [10]. It is ecologically and economically worthwhile to harvest older trees with a gross dimension [11]. This way the forests could store higher amounts of carbon and develop more quality timber. In selection harvest systems, individual trees or small groups of trees are harvested at periodic intervals. The selection is primarily based on their physical condition or degree of maturity [12]. Also the target diameter harvesting regime leads away from whole clearcut areas as a method of final harvesting when individual trees have reached a certain diameter rather than when stands have reached rotation age [13]. So the harvesting results in a forest without large gaps but with less density, decreased averaged height, diameter at breast heigt (DBH), leaf area index (LAI) and vertical distribution of leaf area density (LAD).

The driving force behind the forest damages dynamics is the climate impact; however the magnitude and sign of resulting effect depend on tree species, management method and soil conditions. The projected increasing frequency of severe storms might produce wide area damage in European forest ecosystems during the $21^{\text {st }}$ century [14-18]. It was pointed out that forest management using adequate decision support systems (DSS) can considerably reduce the risk of damages [19]. The DSS "Forest and Climate Change" which is currently being developed at the Göttingen University [20] is aimed to provide a tool for the quantitative assessment of biotic and abiotic risks of forest ecosystems under the 
Table 1. Stand Characteristics and Model Parameters for Different Harvest Intensities of Norway Spruce and European Beech. The Sources of Data are Given in [32]

\begin{tabular}{|c|c|c|c|c|c|c|c|}
\hline \multirow{2}{*}{ Parameter } & Unit & \multicolumn{3}{|c|}{ Norway Spruce } & \multicolumn{3}{|c|}{ European Beech } \\
\hline Variante & & $\mathbf{s p 1}$ & $\mathbf{s p 2}$ & $\mathbf{s p 3}$ & be1 & be2 & be3 \\
\hline \hline age & years & 90 & 90 & 90 & 120 & 120 & 120 \\
\hline stand density & tree ha ${ }^{-1}$ & 371 & 294 & 222 & 202 & 171 & 131 \\
\hline tree height & $\mathrm{m}$ & 27.5 & 26.8 & 26.1 & 30.3 & 30.2 & 29.3 \\
\hline DBH & $\mathrm{cm}^{3}$ & 38.6 & 35.8 & 33.4 & 44.6 & 43.9 & 40.0 \\
\hline solid volume & $\mathrm{m}_{(\mathrm{s})} \mathrm{ha}^{-1}$ & 519 & 351 & 228 & 486 & 395 & 243 \\
\hline max leaf are index & $\mathrm{m}^{2} \mathrm{~m}^{-2}$ & 6.6 & 4.6 & 3.1 & 7.2 & 5.1 & 3.4 \\
\hline relative winter LAI & {$[-]$} & 0.8 & 0.8 & 0.8 & 0.15 & 0.22 & 0.32 \\
\hline stem area index (SAI) & $\mathrm{m}^{2} \mathrm{~m}^{-2}$ & 1.40 & 0.96 & 0.63 & 0.55 & 0.45 & 0.29 \\
\hline
\end{tabular}

conditions of changing climate. An improved understanding of damages is essential for addressing the environmental and policy implications of climate variability and global change. Therefore the objective of this study is to assess the spatiotemporal variability of the effect which different target diameter harvesting (TDH) regimes excersize on wind damage risks for two typical for Germany tree species (spruce and beech) on different soil types under the projected future climatic conditions.

\section{MATERIALS AND METHODOLOGY}

\section{Investigation Area and Tree Species}

The Solling area belongs to German Highlands covering the sub-montane and the montane zone up to $550 \mathrm{~m}$ a.s.1. The area chosen for the study is located between $51.5^{\circ} \mathrm{N}$ and $52.1^{\circ} \mathrm{N}$ and between $9.3^{\circ} \mathrm{E}$ to $9.9^{\circ} \mathrm{E}$, i.e. about $3600 \mathrm{~km}^{2}$ is chosen for the investigation. The area belongs to the suboceanic climate with strong orographic effect on both temperature and precipitaion. For the period 1950-2000 $\mathrm{T}_{\mathrm{a}}$ in the investigation area was between $6.5^{\circ} \mathrm{C}$ and $9^{\circ} \mathrm{C}$, the mean annual precipitation between $600 \mathrm{~mm}$ and about $1000 \mathrm{~mm}$ [21]. The measurement data show [22] that during the period 1969-2002 the decadal mean values of both $T_{a}$ and annual precipitation sums have an increasing tendency in Solling area. While the temperature increases both in summer and in winter, the increase of annual precipitation is caused mainly by the raise of winter precipitation. The mean annual precipitation sum for the mentioned period was $1095 \mathrm{~mm}$ while for the last decade (1190-2002) it reached $1193 \mathrm{~mm}$.

The soils on sandstones and pure sand sediments are generally very acid nutrient poor dystric cambisols [23] and on loess-dominated sites eutric cambisols and haplic luvisols. The forest covers about $42 \%$ of the study area, with the share of deciduous about $26 \%$, coniferous - $11 \%$ and with $5 \%$ of mixed forests (Fig. 1). Fig. (1) shows the spatial distribution of the land-use classes in the study area based on the Corine Land Cover 2000 dataset.

\section{Forest Management Scenarios}

In order to study the influence of stand structure changes caused by forest management activities on stand resistance to wind damage two scenarios of TDH and a reference unmanaged stand are simulated. The calculations of all scenarios were performed for pure stands of both species spruce and beech - and for a mixed stand. As reference unmanaged stands for beech (be1) and spruce (sp1) we use mature stands of the second yield class [24] with a DBH correction according to [25]. In the second variant of beech (be2) all trees with $\mathrm{DBH} \geq 60 \mathrm{~cm}$ are harvested. In the third (be3), the target diameter for harvesting was set on $50 \mathrm{~cm}$. The two different utilisation scenarios for spruce are on 45 $\mathrm{cm}(\mathrm{sp} 2)$ and on $40 \mathrm{~cm}(\mathrm{sp} 3)$. The diameter distribution and the effects of these harvesting scenarios on the mean stand characteristics are modeled with the forest simulator BWinPro7 [26]. The resulting stand parameters are summarized in Table 1. To simulate the risks for mixed stands with equal shares of beech and spruce the simulations were carried out for pure spruce and beech stands separately and the resulting risks were averaged with correspondent (in this case - equal) shares [27].

\section{Climate Scenarios}

To represent the possible future climatic conditions, the modeling results of two Special Report on Climate Scenarios (SRES) climate projections A1B and B1 for the period of 20012100 as well as $20^{\text {th }}$ century scenario C20 for the period of 1960-2000 are used as defined in German framework program "klimazwei". The calculations done by coupled general circulation model - ocean model, ECHAM5-MPIOM, and dynamically downscaled using Climate Local Model, CLM [28] to a spatial resolution of $0.2^{\circ} \times 0.2^{\circ}$ (two runs per scenario) are obtained from CERA data base [29]. For all variables the time series of runs 1 and 2 of $\mathrm{A} 1 \mathrm{~B}$ and $\mathrm{B} 1$ are merged with correspondent runs of $\mathrm{C} 20$ so that continuous time series from 1960 to 2100 are built for both runs of A1B and B1. The calculations of wind damage risks with CLM data have been carried out according to the recommendations of [30]. Spatial averaging over the 9 CLM grid points to represent the study area is carried out for all climate characteristics. The calculations of abiotic risks have been done with daily resolution, separately with runs 1 and 2 for both merged C20$\mathrm{A} 1 \mathrm{~B}$ and $\mathrm{C} 20-\mathrm{B} 1$. The results for each run are aggregated to annual means. To describe the tendencies of climate development the spatial mean values are then averaged over the 30-years periods: 1981-2010 (P0) - assumed as "actual state" or "reference period", 2011-2040 (P1), 2041-2070 (P2) and 2071- 


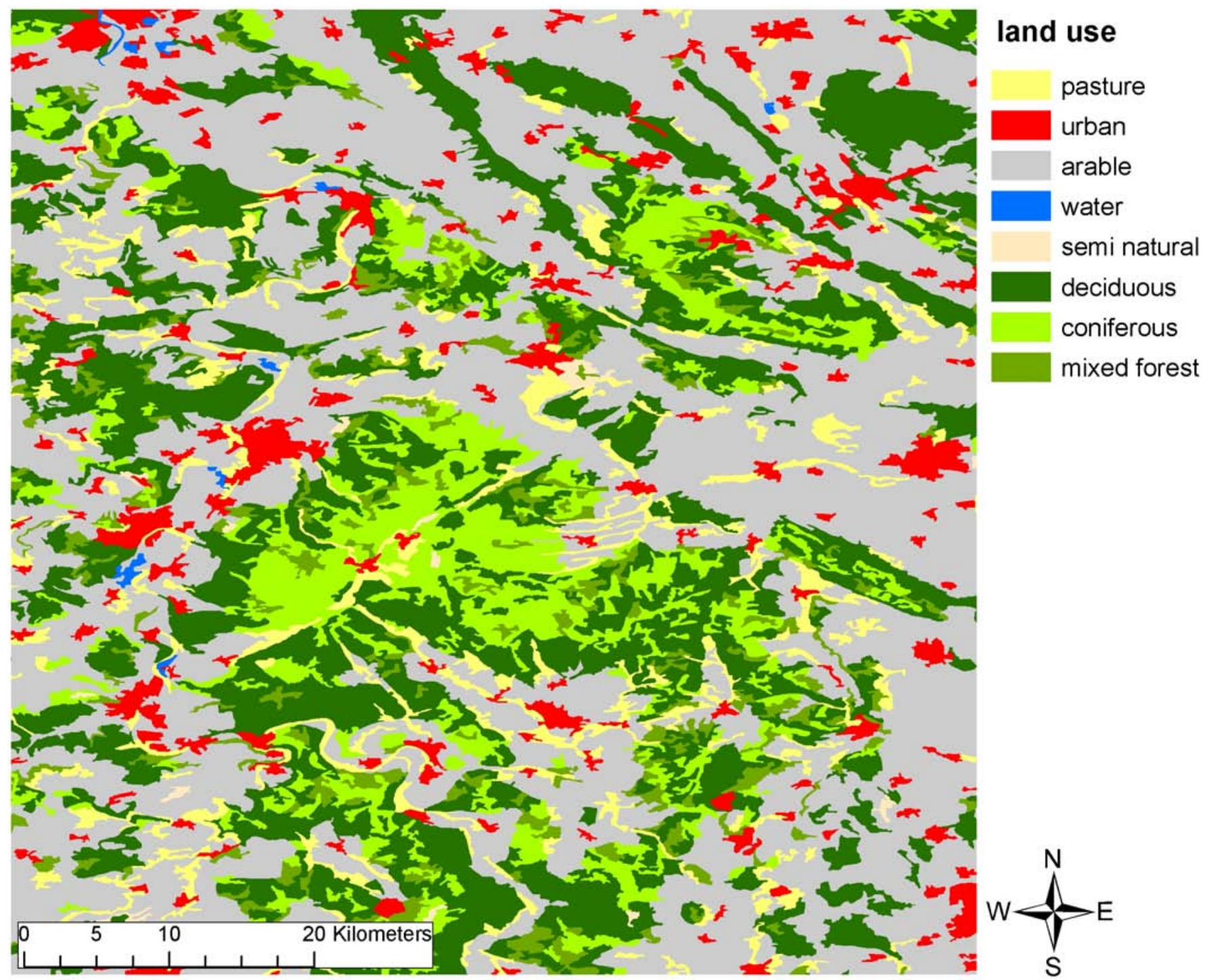

Fig. (1). Map of Solling site showing the different land use based on CORINE Land Cover 2000; Umweltbundesamt, DLR-DFD 2004.

$2100(\mathrm{P} 3)$ and relative differences are calculated: $\Delta \varphi_{\mathrm{i}}=\left(\varphi_{\mathrm{i}}-\varphi_{0}\right) /$ $\varphi_{0} * 100 \%$, where $\varphi_{i}$ is the 30 -years mean value of the spatially averaged climate variable listed above for the climatic period $\mathrm{i}=$ $0,1,2,3$.

\section{Soil and Root Parameters}

For the spatially distributed simulation we used the digital soil map of Germany at a scale of 1:1000000 [31] and the digital metadata corresponding to the mentioned soil map. This map is subdivided accordingly to the main land cover types (forest, cropland and grassland).

The architecture of root systems is influenced by species and age of trees, soil properties, the depth of ground water and thus, indirectly by climate conditions. The detailed description of soil and root modeling approach is given in [32].

\section{Preprocessing of GIS Coverage's and Input Datasets}

To combine the spatial information the joint "look up table" is created with the unique attributes for each coverage within the model area. The first step has been to construct this table in ArcGis (Version 9.2; ESRI inc., Redlands, CA), which is the unique superposition of the climate, soil and land-use GIS-data layers. In the second step the constructed dataset is used for the initialization of the model runs. The simulations are run for forest sites only.

\section{Models Description (BROOK 90)}

To simulate the water balance of forest stands in this paper we use the BROOK90 (Version 4.4e) - a 1D-SoilVegetation-Atmosphere Transfer (SVAT) Model [33-35]. BROOK90 has been developed to be applicable to different and changing land use. It simulates interception by a single layered stand, evapotranspiration, soil water and a streamflow consisting of surface runoff, bypass flow, down slope flow and base flow. The soil water transport is simulated with the Darcy-Richard equation. BROOK90 is a detailed, process-oriented model that can be used to study the soil water budget of forest stands over a broad set of study sites (e.g. [36-40]).

\section{Models Description (SCADIS)}

The atmospheric boundary-layer model SCADIS [2, 4] based on E- $\omega$ scheme (where E is turbulent kinetic energy 
and $\omega$ is the specific dissipation of E) was used. The twoequation closure approach does not require a predefined mixing length and is thus naturally suited to modeling atmospheric flows over heterogeneous surfaces. Modification of model constants implemented in the model according to [3] extends the generality and applicability of approach to inhomogeneous canopy flow. This modification was found robust and performed well for wide range of canopies. To be driven the canopy flow model requires minimal set of tractable parameters describing canopy properties such as LAD and aerodynamic drag coefficient $\mathrm{C}_{\mathrm{d}}$. Model equations and details about numerical schemes and boundary conditions can be found in above mentioned papers.

\section{Critical Wind Speed (CWS) and Risk Assessment}

The CWS for windbreak, $\mathrm{CWS}_{\text {break }}$, and for overturning, $\mathrm{CWS}_{\mathrm{ot}}$, defined as the speed at the tree tops, are calculated as in ForestGALES. The detailed description and discussions of the approach are given in $[19,41]$. Here the main equations are shown:

$$
\begin{aligned}
& C W S_{\text {break }}=\frac{1}{\kappa D}\left[\frac{\pi M O R * D B H^{3}}{32 \rho G(d-1.3)} \frac{f_{\text {knot }}}{f_{C W}}\right]^{\frac{1}{2}} * \\
& \ln \left(\frac{h-d}{z_{0}}\right) \\
& C W S_{o t}=\frac{1}{\kappa D}\left[\frac{C_{r e g} * S W}{32 \rho G d} \frac{f_{\text {knot }}}{f_{C W}}\right]^{\frac{1}{2}} \ln \left(\frac{h-d}{z_{0}}\right)
\end{aligned}
$$

where $\kappa=0.41$ is von Karman's constant, $\mathrm{d}(\mathrm{m})$ is the zeroplane displacement, $\mathrm{z}_{0}(\mathrm{~m})$ is the aerodynamic roughness, $\mathrm{D}(\mathrm{m})$ is the average spacing between trees, $\mathrm{DBH}(\mathrm{m})$ is diameter at breast height ( $1.3 \mathrm{~m}$ above ground $), \mathrm{h}(\mathrm{m})$ is mean tree height (Table 1) and $\rho\left(1.226 \mathrm{~kg} \mathrm{~m}^{-3}\right)$ is the dry air density. $\mathrm{C}_{\text {reg }}\left(\mathrm{N} \mathrm{m} \mathrm{kg} \mathrm{k}^{-1}\right.$ ) is a regression constant that is dependent on soil and rooting depth and $\mathrm{SW}(\mathrm{kg})$ is the stem weight of the tree. The factors $\mathrm{f}_{\text {knot }},(=0.85)$ and $\mathrm{f}_{\mathrm{CW}}(=1.17)$ account for the reduction in wood strength due to knots and the additional load due to the overhanging weight of the tree displaced from the vertical position by the wind stress. The $\mathrm{f}_{\text {edge }}$, taking into account the position of the tree relatively to the forest edge is ignored because of the assumption of horizontal homogeneity. $\mathrm{G}$ is a dimensionless gust factor [9, 41]:

$$
G=18.585-28.35 \cdot \frac{D}{h}+1.59165 \cdot \ln \left(\frac{D}{h}\right)
$$

Influence of rooting depth was taken into account. We assume that the tree anchorage and consequently the CWS estimated by means of functions based on tree pulling experiments are valid for "average" species-specific effective rooting depths: $0.91 \mathrm{~m}$ for spruce and $1.3 \mathrm{~m}$ for beech. Then the deviations of rooting depths from these mean values caused by combination of tree species and soil type [42] produce a correspondent linear positive or negative deviations from mean tree anchorage [43-45] and, thus, deviations of CWS from the initial "average" value.
In general, the risk of windthrow increases with increasing soil moisture content because of the weakening of tree anchorage and consequent reduction of CWS [46]. As a dynamic indicator of the soil moisture status, we use the time-dependent relative extractable soil water, $\operatorname{REW}(\mathrm{t})$, which is calculated with the daily timestep as the ratio of actual to maximum extractable water according to [47]:

$R E W(t)=\frac{\theta_{v}(t)-\theta_{R}}{\theta_{f c}-\theta_{R}}$

where $\theta_{v}\left[\mathrm{~m}^{3} \mathrm{~m}^{-3}\right]$ is the actual (correspondingly - daily) volumetric (subscript "v") soil water fraction; $\theta_{\mathrm{fc}}\left(\mathrm{m}^{3} \mathrm{~m}^{-3}\right)$ is the maximum soil water content extractable by plants (subscript "fc" means field capacity), and $\theta_{\mathrm{R}}\left(\mathrm{m}^{3} \mathrm{~m}^{-3}\right)$ the residual soil water content. We distinguish between dry and wet soil conditions where the wet conditions mean that the soil moisture has exceeded a certain threshold and the tree anchorage starts to decrease. As there are no published data on the critical level of soil moisture, the threshold of REW(t) $\geq 0.6$ is chosen in this study because at this level the optimum water content has been exceeded [48, 49]. The rate of mineralization, used as a proxy, slows down which indicates the prevailing anaerobe conditions and consequently filling the most soil pores with water. The moistening of the soil beneath a soil-root plate reduces the trees resistance to wind [50]. Therefore, we assumed for free draining soils that when $\operatorname{REW}(\mathrm{t})$ exceeds 0.6 the CWS decreases linearly:

$$
C W S(t)=\left\{\begin{array}{cc}
\frac{C W S_{o t} * 0.6}{R E W(t)} ; & R E W(t) \geq 0.6 \\
C W S_{\text {break }} ; & R E W(t)<0.6
\end{array}\right.
$$

The risks are quantified as a share of damaged vegetation in total stand $(0 \leq \mathrm{SH} \leq 1)$ which is a function of wind load. The minimal speed leading to windthrow is $\mathrm{CWS}_{\min }=8 \mathrm{~m} \mathrm{~s}^{-1}$ (correspondent load is denoted as $\mathrm{F}_{\mathrm{Vmin}}$ ) and the wind speed of $\mathrm{CWS}_{\mathrm{abs.max}}=40 \mathrm{~m} \mathrm{~s}^{-1}$ is set as the load of full damage, i.e. all trees in stand are damaged [51] (correspondent load is denoted as $\mathrm{F}_{\text {Vabs,max }}$ ). The relative load provided by actual wind is then:

$$
\begin{aligned}
& F_{a c t}=1-\frac{F_{V a b s, \text { max }}-F_{V a c t}}{F_{V a b s, \text { max }}-F_{V \text { min }}} \text { and } \\
& S H=1-F_{a c t}^{b}, \mathrm{~F}_{V \text { act }} \geq \mathrm{F}_{V \text { min }}
\end{aligned}
$$

where $b=3.73$ is the best approximation of damage curves for unmanaged stand presented by [51]. To assess the effects of forest structure changes resulting from windthrow events on the probability of next damage event the calculations are carried out in two ways. First - the damage is summed up during the 30-years period, but the forest structure does not change. Second - the damage is summed up and the damaged trees are "removed" from the stand - accordingly the stand density and LAI decrease. The calculations with BROOK90 continue from the time point of damage with the new values of structural characteristics. The stand's microclimate changes which in turn enhances or inhibits the 
following windthrow events thus creating positive or negative feedbacks.

\section{Initial and Boundary Conditions}

The simulation period started on the 1.1.1960, whereby the evaluations were accomplished for the following four periods: P0: 1981-2010, P1: 2011-2040, P2: 2041-2070, P3: 2071-2100. The period 1960-1980 is used as an initialization run. Due to the long initialization time from 1960 to the first analysis period the soil profiles were assumed to be saturated at the beginning, with an initial matrix potential of $-10 \mathrm{kPa}$ for all locations and horizons. To reach a maximum of simulation speed, the partial differential equations were solved with a maximum of 20 iterations per day. The minimum allowed iteration time step for BROOK90 is " 2 " [1]. The maximum change in soil wetness or saturation fraction for any layer in iteration was set to $0.5 \%$. For all locations at the bottom of the soil $(2 \mathrm{~m})$ free drainage was accepted.
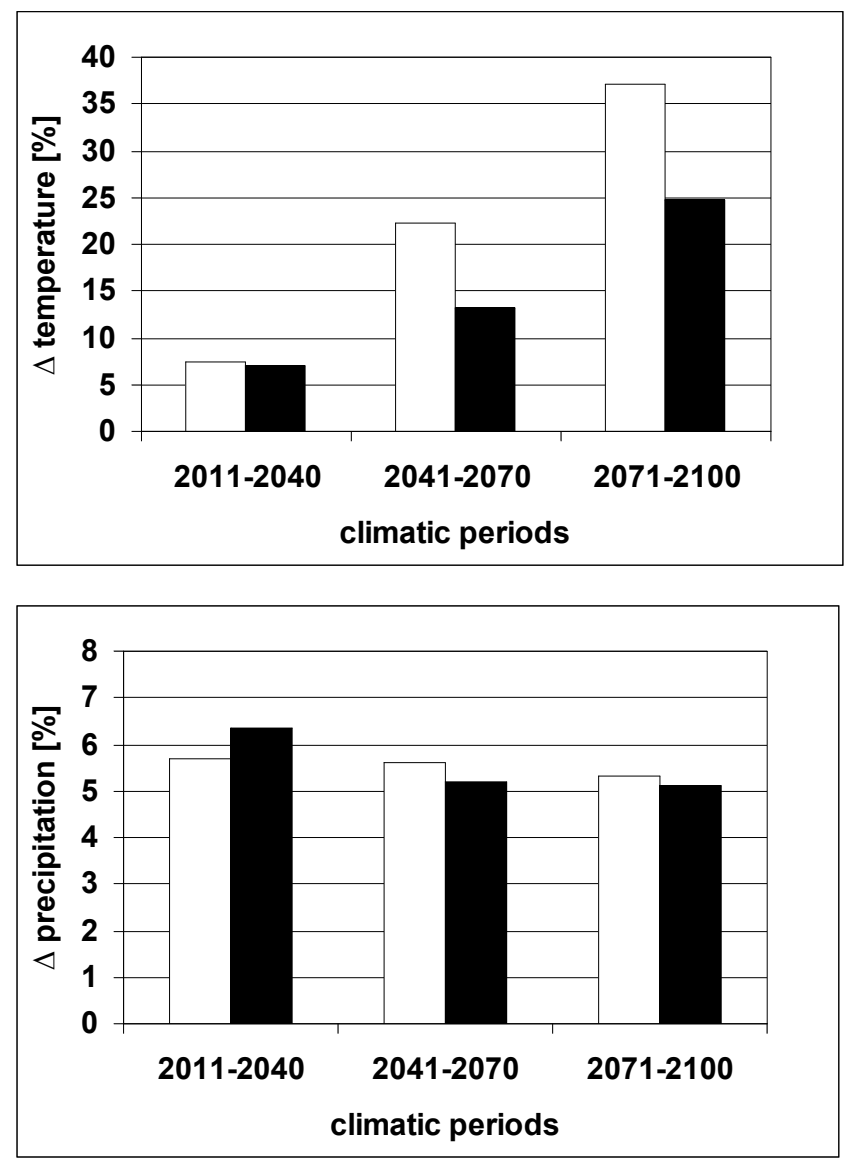

Fig. (2). The changes of annual mean values of air temperature (upper panel) and precipitation (lower panel) averaged over 30years climatic periods relatively to the reference period $(\mathrm{P} 0=1981$ 2011) for two SRES scenarios: $\square$ : A1B and $\mathbf{m}$ : B1.

\section{RESULTS AND DISCUSSION}

\section{Climate Conditions}

To characterize the projected climate conditions in $21^{\text {st }}$ century in Solling area the CLM-data were post-processed according to the recommendations of [30]. The data of A1B_1, A1B_2, B1_1 and B1_2 are aggregated to annual means (sums in case of precipitation). Spatial averaging over the 9 CLM grid points is carried out for all mentioned climate characteristics in order to represent the study area.

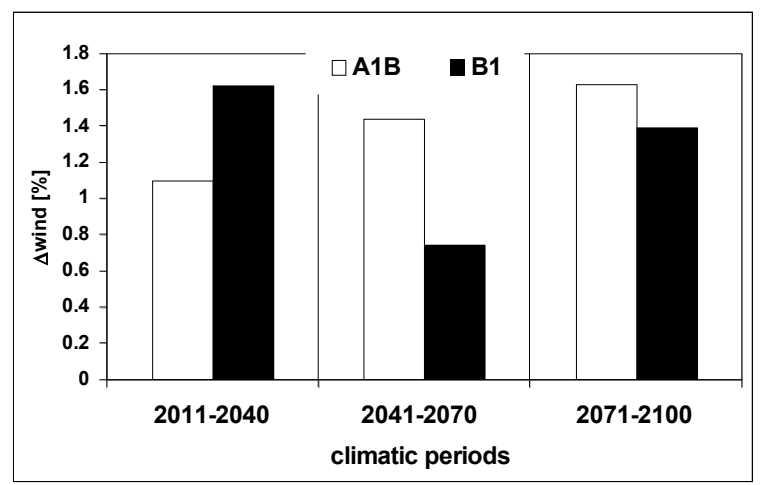

Fig. (3). The changes of annual mean values windspeed averaged over 30-years climatic periods relatively to the reference period (P0= 1981-2011) for two SRES scenarios: $\square$ : A1B and $\mathbf{m : ~ B 1 . ~}$
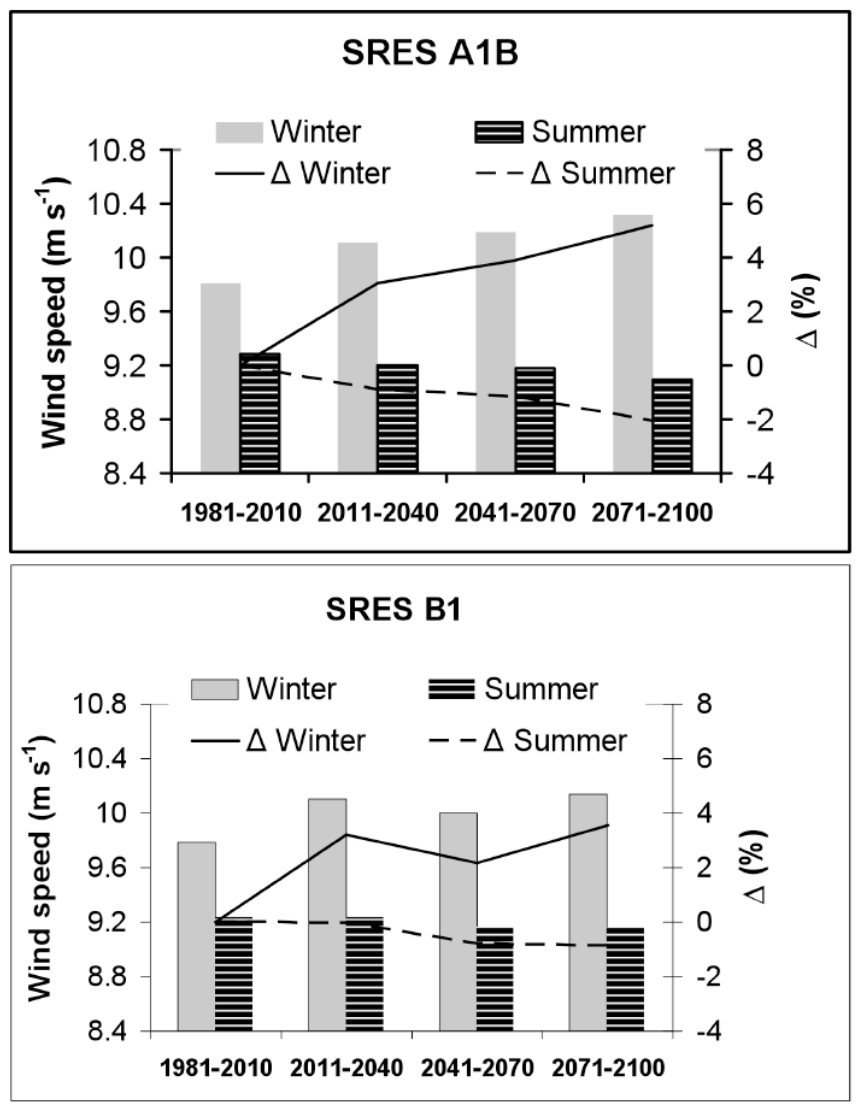

Fig. (4). The changes of seasonal mean values of windspeed averaged over 30-years climatic periods absolute values and relative to the reference period $(\mathrm{P} 0=1981-2011)$ for two SRES scenarios: A1B (upper panel) and B1 (low panel). The vertical bars indicate the wind speed (left $\mathrm{Y}$-axis); the lines indicate the relative changes, $\Delta$ (right $\mathrm{Y}$-axis).

The spatial variations within the chosen area are very low so that the spatial means are assumed to be representative. To describe the tendencies of climate development the spatial mean values of meteorological variables are averaged over the 30-years periods: P0-P3 and relative differences are calculated as described above in subsection "climate scenarios". The analysis of climate scenarios data shows 
(Fig. 2) for both scenarios an increase of precipitation to $\Delta \mathrm{P}_{1} \approx 6 \%$ and then slight monotonical decrease towards 2100 to $\Delta \mathrm{P}_{3} \approx 5 \%$. However, the air and soil temperatures increase monotonically and rather strongly towards P3 with $\Delta \mathrm{T}_{3}>37 \%$ in $\mathrm{A} 1 \mathrm{~B}$ and $\Delta \mathrm{T}_{3}>24 \%$ in $\mathrm{B} 1$.

In both scenarios the daily mean $\left(\mathrm{V}_{\mathrm{av}}\right)$ (Fig. 3) and maximal wind velocity $\left(\mathrm{V}_{\max }\right)$ (not shown) do not change strongly during $21^{\text {st }}$ century. In $\mathrm{A} 1 \mathrm{~B}$ both $\mathrm{V}_{\mathrm{av}}$ and $\mathrm{V}_{\max }$ increase continuously towards $\mathrm{P} 3$ with $\Delta \mathrm{V}_{\mathrm{av}}, 3$ going up to $2.3 \%$ and $\Delta \mathrm{V}_{\max , 3}$ up to $1.6 \%$. In $\mathrm{B} 1$ the strongest increases $1.6 \%$ for $\Delta \mathrm{V}_{\max }$ and $2.2 \%$ for $\Delta \mathrm{V}_{\mathrm{av}}$ occur from $\mathrm{P} 0$ to $\mathrm{P} 1$ exceeding the correspondent $\Delta \mathrm{V}_{\text {max }}$ and $\Delta \mathrm{V}_{\mathrm{av}}$ values for A1B. They decrease to P2 and increase slightly again in P3. Fig. (4) shows that the tendencies of annual mean wind speed are mainly caused by the pattern of mean winter windspeed. The mean wind in summer decreases monotonically with changes up to $2 \%$ under A1B and less than $1 \%$ under $\mathrm{B} 1$. That compensates partially the rather high increases of mean wind in winter - up to $6 \%(\mathrm{P} 3)$ under A1B and up to $4 \%$ (P3) under B1.

\section{Model Results and Discussion}

To analyse the impact of TDH on spatial and temporal pattern of windthrow risk the calculations are carried out separately for separate runs: A1B_1, A1B_2, B1_1 and B1_2 and then aggregated to 30 -years-period means. Finally the soil and forest type distributions are superimposed with climate data and the damage risks are calculated. The results are the absolute differences between damaged share of trees in stands during the reference period (P0) and climate periods (P1-P3) for spruce and beech stands managed by different TDH (sp2, sp3, be2, be3).

Fig. (5) shows that in average in the investiated area the future changes in climate conditions will result in a very weak increase of wind damage from about $3 \%$ in P0 to approximately $5 \%$ in $\mathrm{P} 3$. The magnitudes of changes are very similar for both scenarios. It is however clearly visible that the climatic factor which controls the changes of wind risks is the wind speed - the temporal course of damages follows the pattern of changes in the windspeed (Figs. 3, 4). While the increase of windspeed and wind damage under $\mathrm{A} 1 \mathrm{~B}$ is weak but monotonical, the changes under B1 are also weak but experience a slight decrease between P1 and P2 caused by decrease of changes in wind speed and by winter mean in particular (Fig. 4).

The changes from P0 to P1 are stronger for B1 because of stronger increase in windspeed and precipitation in this period.

Figs. $(6,7)$ demonstrate that within the investigated area the damage risks vary considerably from almost no damage to more than $40 \%$ so that the area-averaged estimation should be used with care. However, it is demonstrated that the spatial patterns of damage under A1B and B1 are very similar and correspond to the distribution of forest types (Fig. 1). Considering the climate development in $21^{\text {st }}$ century one can see that the damage risks increase towards 2100 both under $\mathrm{A} 1 \mathrm{~B}$ and $\mathrm{B} 1$ conditions. The spatial pattern of risks does not undergo any notable changes so that the "hot spots" of high damage remain on same places, but increase in magnitudes. Considering the influence of the harvesting regime one can see that the forest management has generally an immediate destabilizing effect on forest ecosystems which was also concluded by [6]. The harvesting of highest trees in a stand results in a decreasing of mean stand height and thus should contribute to the stand stabilization. However, the increasing of mean distance between trees which is one of the key variables influencing the CWS results in the strong decreasing of the CWS and thus to stand's destabilization. On the other hand the reduced tree cover and LAI results in the complicated interactions of location- and species-dependent factors leading to decrease or increase of soil water content [7]. This respectively can lead to stabilizing or destabilizing of forest stands. Figs. (6, 7) show that under both $\mathrm{A} 1 \mathrm{~B}$ and $\mathrm{B} 1$ scenarios and under the conditions of Solling the TDH variants sp2,3 and be2,3 invariably lead to the destabilization for both species and all locations (soils). The magnitude of TDH contribution to the destabilization of stands remains almost constant towards 2100. It indicates that the contribution of the stand density to destabilization is higher than of the increase of soil water content. Comparing the spatial patterns of damage in unmanaged stand, sp1, be1 to sp2, 3 and be 2, 3 one can see that while the damage pattern in managed stands is similar to the unmanaged ones, the patterns of intensity increments differ for different TDH regimes. The reasons are the different magnitudes of destabilisation for beech (lower) and spruce (higher effect). On example of unmanaged stand in reference period P0 the Fig. (8) shows the spatial distribution of wind damage risks superimposed on forest types. One can clearly see that the highest damage - up to $17 \%$ occurs in coniferous stands. Most of the beech stands remain within the range of $2.5 \%$ with the "hot spot" - up to $5 \%$. In the mixed stand the damage risks are consequently within the range of $10 \%$. Thus the beech stands have generally lower risks than spruce in spite of the lower stand density. The reason is that other factors such as: lower mean stand height, deeper rooting and lower slenderness ( $\mathrm{h} / \mathrm{DBH}$ ratio) provide higher stabilizing effect for beech stands compared to spruce.

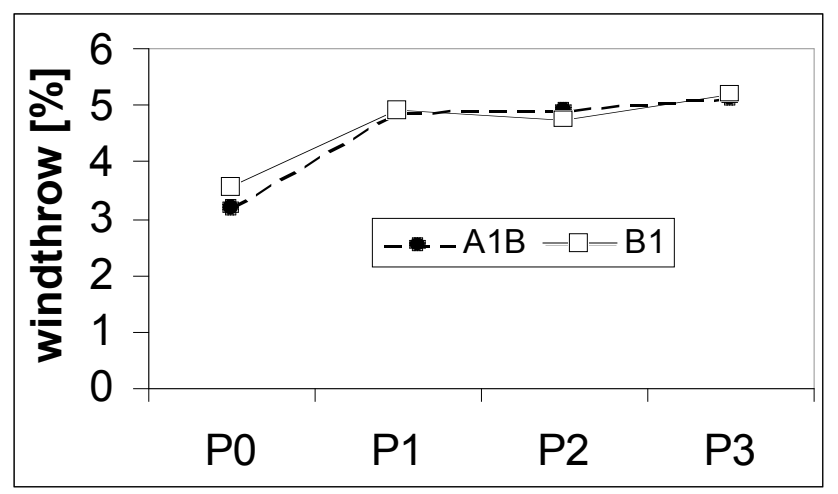

Fig. (5). The changes of area-averaged 30-years mean values of windthrow damage in Solling area for two SRES scenarios: A1B and $\mathrm{B} 1$.

The averaged over species stand damage (Fig. 9) shows that under both climate scenarios the damage risks for spruce increase monotonously towards 2100 . The temporal course of risks for beech stands is completely different. The risks increase slightly from P0 to P1 and then decrease continuously toward P3. 


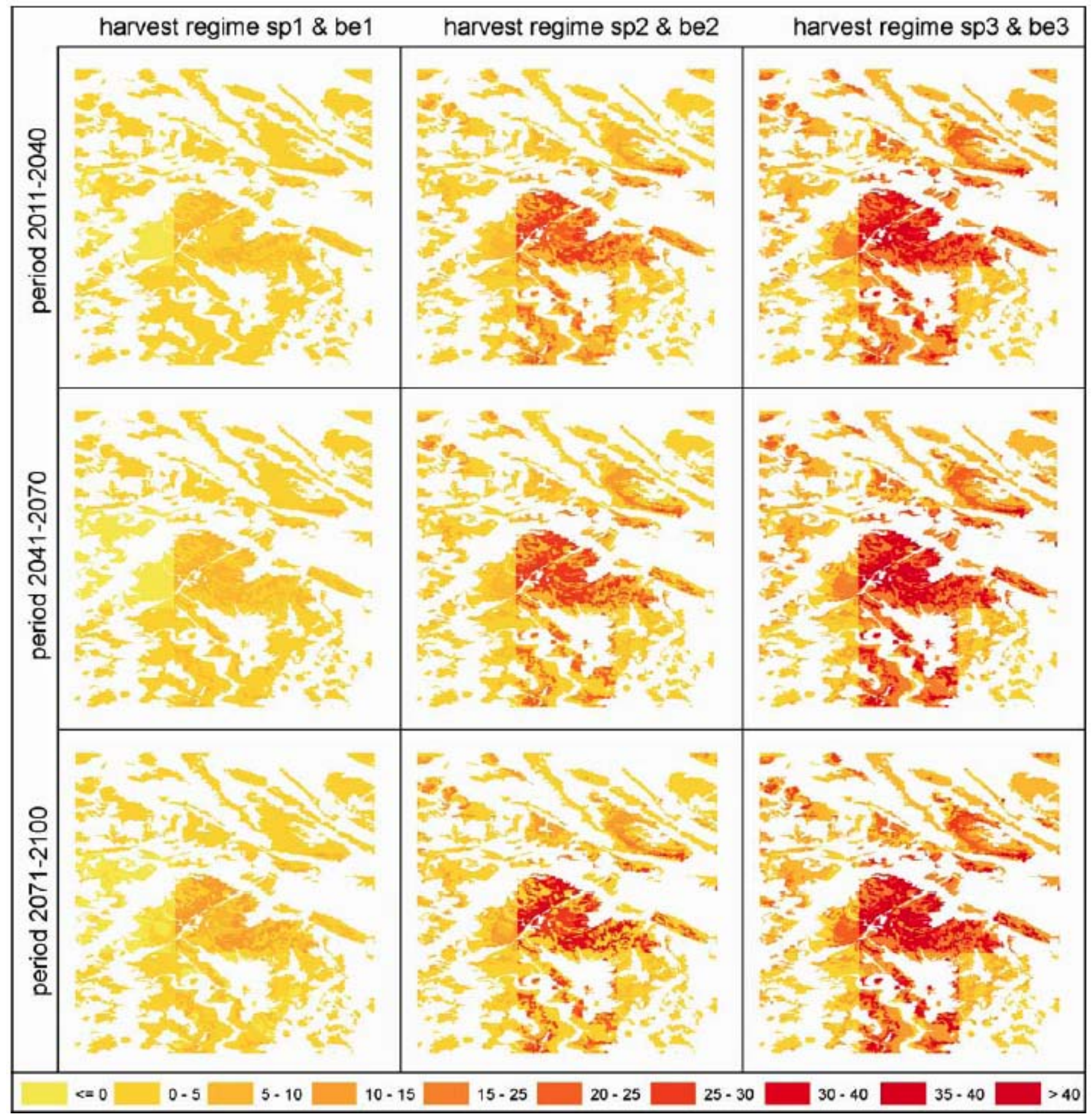

Fig. (6). Spatial and temporal variations of wind damage risks (\%) in forest ecosystems for different target diameter harvest regimes under A1B climate change conditions, presented as differences between mean annual wind risks for a given period and P0.

\section{CONCLUSIONS}

The present study has shown that according to the climate scenarious A1B and B1 regionalized with CLM the air temperature in Solling area is likely to increase monotonically towards 2100 . The changes are considerable up to $37 \%$ under $\mathrm{A} 1 \mathrm{~B}$ and up to $25 \%$ under $\mathrm{B} 1$. The changes of precipitation are within $6.5 \%$ only whereas the maximal increase is projected for P1 (2011-2040). The wind speed is likely to increase weakly - up to $1.6 \%$ compared to present conditions. Therefore, in unmanaged stands the increment of wind risks towards 2100 compared to "present climate conditions", is mainly caused by the changes in annual precipitation and increase of mean air temperature. However the temporal course of risks development depends on the evolution of windspeed.

Among the non-meteorological variables determining risks of windthrow the key factors are the distance between trees, $\mathrm{h} / \mathrm{DBH}$ ratio, rooting depth and soil moisture.

The risks for unmanaged spruce are higher than for beech stands and the risks for beech stands start to decrease after 


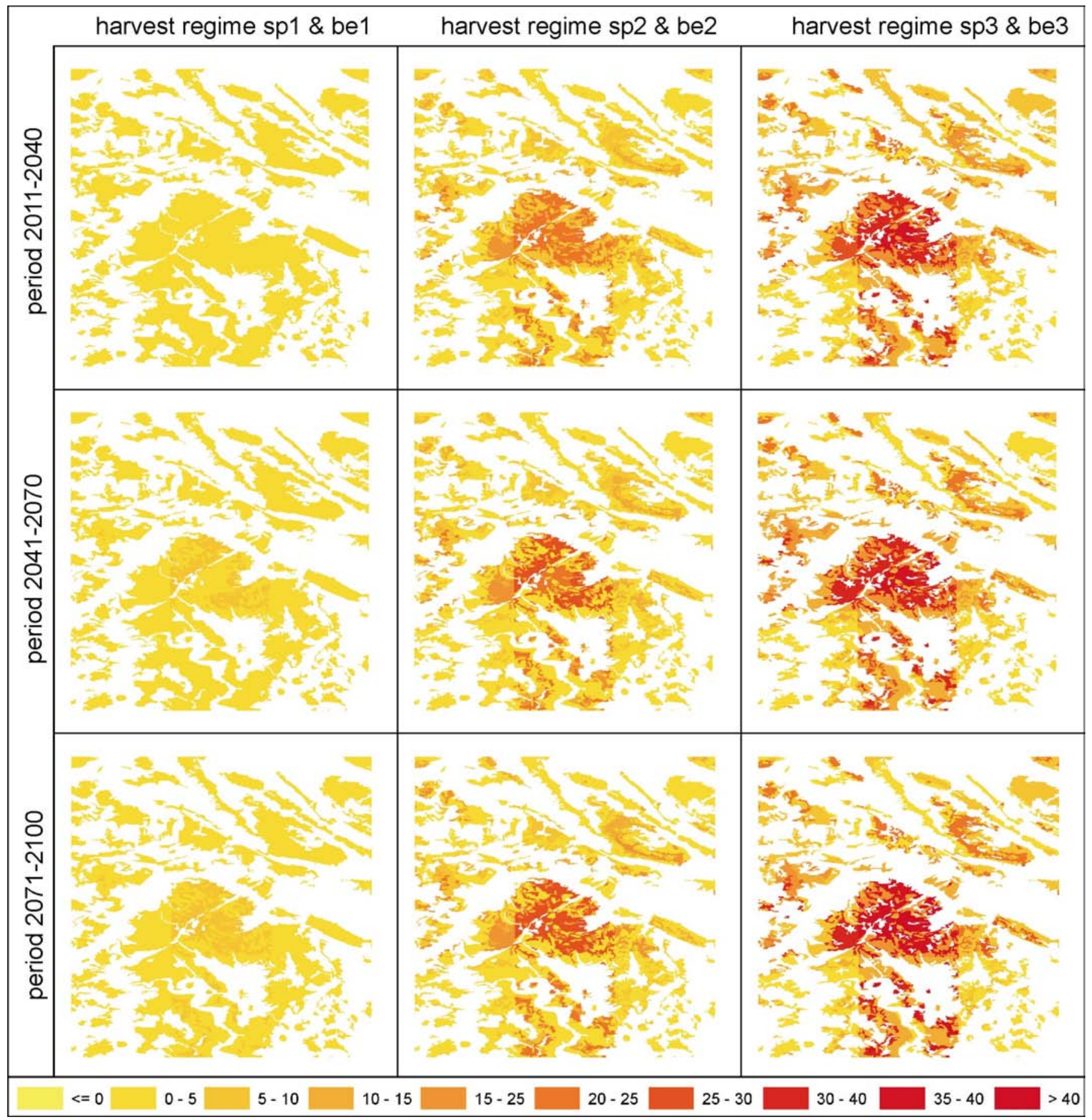

Fig. (7). Spatial and temporal variations of wind damage risks (\%) in forest ecosystems for different target diameter harvest regimes under $\mathrm{B} 1$ climate change conditions, presented as differences between mean annual wind risks for a given period and P0.

2040. Thus it could be concluded that for different locations and combinations of meorological variables different key factors will control the magnitude and the distribution of wind risks. The spatial distribution of damage and its dynamics depend on the superposition of forest types, soils and climatic variables. Therefore the estimation of wind damage risks should be carried out using a coupled model taking into account the dynamic of soil moisture, structural properties for considered tree species and their temporal variability and the dynamic of climatic parameters. It was shown that the proposed method of DSS-WuK demonstrates the ability to describe all mentioned processes. When implemented to the evaluation of wind risks in the managed stands the DSS has shown that the forest management method - TDH tends to destabilize forest stands remaining after harvesting and thus - to increase the future wind damage risks. The higher is the intensity of harvesting - the more unstable against wind stress will be the remaining stand. 


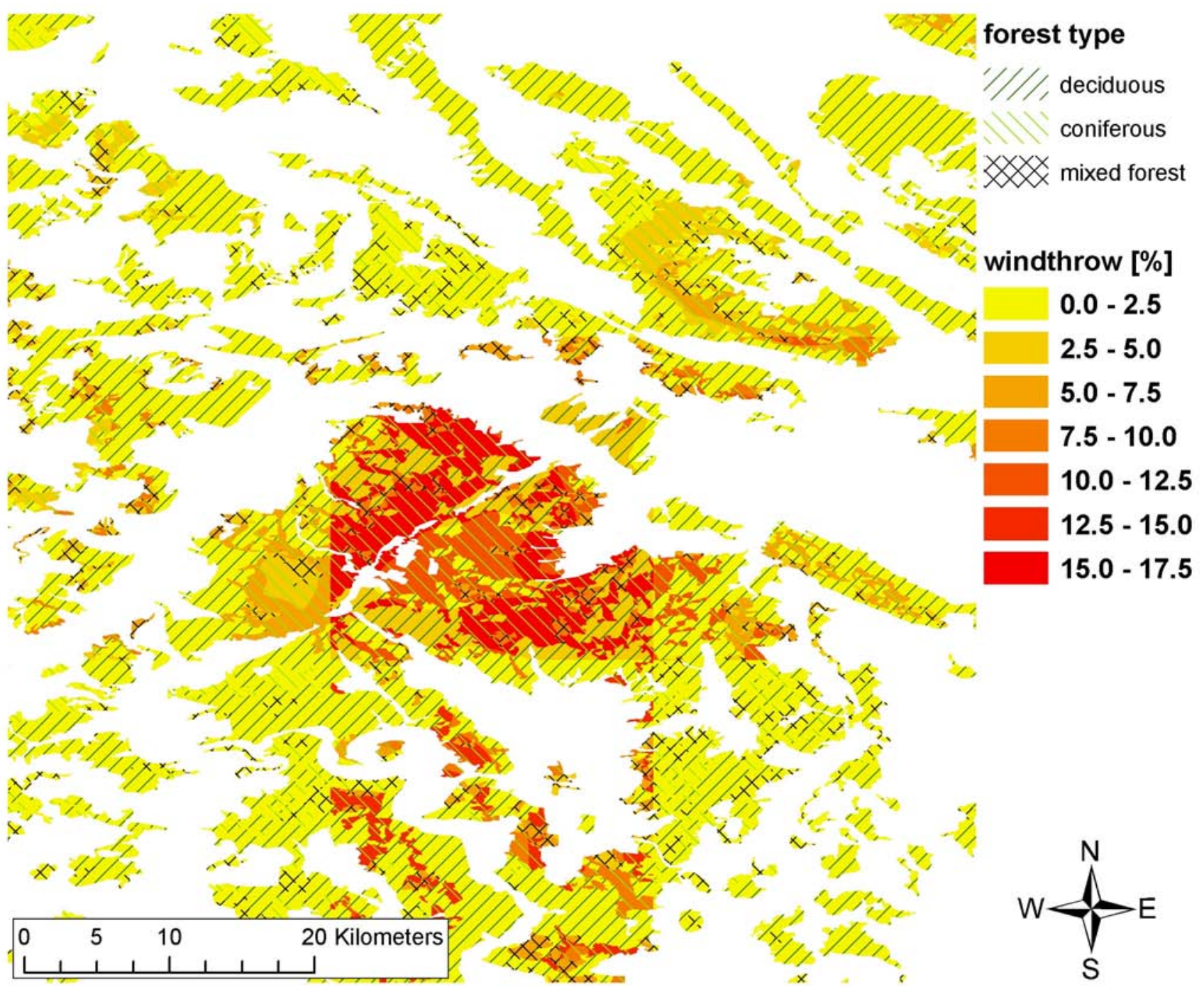

Fig. (8). Superposition of spatial distributions of forest types and wind damage risks in forest ecosystems for reference scenario P0.

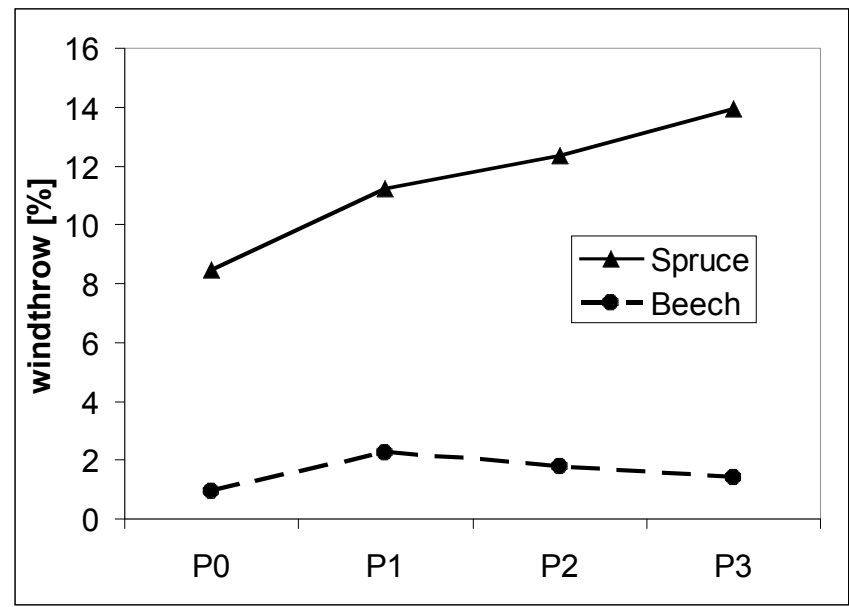

Fig. (9). The changes of scenario-averaged 30-years mean values of windthrow damage in Solling area for Norway spruce and European beech.

\section{ACKNOWLEDGEMENTS}

The study was supported by German Federal Ministry of Education and Research (BMBF) as a joint project "Decision Support System - Forest and Climate Change" (DSS-WuK) within the frames of program "klimazwei - Research for climate protection and protection from climate impacts" and by the Ministry of Science and Culture of Lower Saxony withn the program "Research on Climate Impacts (KLIFF)". We gratefully acknowledge this support.

\section{REFERENCES}

[1] Federer CA. BROOK90: a simulation model for evaporation, soil water and stream flow, Version 3.1. Computer freeware and documentation. USDA Forest Service, PO Box 640, Durham NH 03825, USA 1995.

[2] Sogachev A, Menzhulin G, Heimann M, Lloyd J. A simple three dimensional canopy - planetary boundary layer simulation model for scalar concentrations and fluxes. Tellus 2002; 54B: 784-819.

[3] Sogachev A, Panferov O. Modification of two-equation models to account for plant drag. Boundary Layer Meteorol 2006; 121: 22966. 
[4] Sogachev A. A note on two-equation closure modelling of canopy flow. Boundary-Layer Meteorol 2009; 130: 423-35.

[5] Rockel B, Will A, Hense A. The regional climate model COSMOCLM (CCLM) Ed. Meteorol Zt 2008; 12(4): 347-8.

[6] Gardiner BA, Achim A, Marshall BJ, Belcher RE, Wood CJ. The stability of different silvicultural systems: a wind tunnel investigation. Forestry 2005; 78: 471-84.

[7] Panferov O, Doering C, Rauch E, Sogachev A, Ahrends B. Feedbacks of windthrow for Norway spruce and Scots pine stands under changing climate, Environ Res Lett NEESPI Special Issue, 4 045019 (10pp) doi: 10.1088/1748-9326/4/4/045019.

[8] Panferov O, Sogachev A. Influence of gap size on wind damage variables in a forest. Agric For Meteorol 2008; 148: 1869-19.

[9] Gardiner BA, Stacey GR, Belcher RE, Wood CJ. Field and wind tunnel assessments of the implications of respacing and thinning for tree stability. Forestry $1997 ; 70: 233-52$.

[10] Tarp P, Helles F, Holten-Andersen P, Larson JB. Strange N: modelling near-natural silvicultural regimes for beech - an economic sensitivity analysis. For Ecol Manage 2000; 130: 187-98.

[11] Holten-Andersen P. Economic evaluation of cyclic regimes in beech (Fagus sylvatica L.). Scand J For Res 1987; 2(2): 215-25.

[12] Nyland RD. Silviculture: concepts and applications. New York: McGraw-Hill 2002.

[13] Reininger H. Zielstärken-Nutzung oder die Plenterung des Altersklassenwaldes. Vienna: Österreichischer Agrarverlag 1987.

[14] IPCC: Climate Change 2007: The Physical Science Basis. Contribution of working group I to the fourth assessment. Report of the intergovernmental panel on climate change. Cambridge, United Kingdom and New York, NY, USA: Cambridge University Press 2007.

[15] Tebaldi C, Hayhoe K, Arblaster JM, Meehl GA. Going to the extremes: an intercomparsion of model-simulated historical and future changes in extreme events. Clim Change 2006; 79: 185-211.

[16] Leckebusch GC, Renggli D, Ulbrich U. Development and application of an objective storm severity measure for the Northeast Atlantic region. Meteorol Z 2008; 17(5): 575-87.

[17] Christensen JH, Carter TR, Giorgi F. PRUDENCE employs new methods to assess European climate change. Eos Trans AGU 2002; 83(13): 147.

[18] Leckebusch GC, Ulbrich U. On the relationship between cyclones and extreme windstorm events over Europe under climate change. Global Pan Change 2004; 44(1-4): 181-93.

[19] Gardiner B, Peltola H, Kellomäki S. Comparison of two models for predicting the critical wind speeds required to damage coniferous trees. Ecol Model 2000; 129: 1-23.

[20] Jansen M, Döring C, Ahrends B, et al. Anpassungsstrategien für eine nachhaltige Waldbewirtschaftung unter sich wandelnden Klimabedingungen - Entwicklung eines Entscheidungsunterstützungssystems Wald und Klimawandel (DSS-WuK). Forstarchiv 2008; 79: 131-42.

[21] Hijmans RJ, Cameron SE, Para JL, Jones PG, Jarvis A. Very high resolution interpolated climate surfaces for global land areas. Int $\mathrm{J}$ Climatol 2005; 25: 1965-78.

[22] Panferov O, Kreilein H, Meesenburg H, Eichhorn J, Gravenhorst G. Climatic conditions at three beech forest sites in Central Germany, In: Brumme R, Alphei J, Eds. Human impacts on carbon and nitrogen cycles in temperate beech forests. Springer, Berlin/New York, Germany. Ecol Ser 2009; 208: 13-32.

[23] FAO: Soil Map of the world. Vol 1: Legend. World soil resources report. Rome: Food and Agriculture Organization of the United Nations 1990; vol. 60: p. 119.

[24] Schober R. Ertragstafeln wichtiger Baumarten bei verschiedener Durchforstung. 4. Aufl. Frankfurt am Main: Sauerländer 1995.

[25] Wollborn P, Böckmann T. Ein praktikables Modell zur Strukturierung des Vorrates aus Ertragstafelschätzungen. Forst und Holz 1998; 53(18): 547-50.

[26] Nagel J, Albert M, Schmidt M. Das waldbauliches Prognose- und Entscheidungsmodell BWINPro 6.1. Forst und Holz 2002; 57: 48693.

[27] Armbruster M, Seegert J, Feger KH. Effects of changes in tree species composition on water flow dynamics - Model applications and their limitations. Plant Soil 2004; 264: 13-24.
[28] Rockel B, Castro CL, Pielke RA, von Storch H, Leoncini G. Dynamical downscaling: Assessment of model system dependent retained and added variability for two different regional climate models. J Geophys Res-Atmos 2008; 113: D21107.

[29] Lautenschlager M, Keuler K, Wunram C, et al. Climate simulations with CLM, data stream 3: European region MPI-M/MaD. World data center for climate. DOIs:1) 10.1594/WDCC /CLM_C20_1_ D3; 2) 10.1594/WD CC/CLM_C20_2_D3; 3) 10.1594/WDCC/ CLM_A1B_1_D3; 4) 10.1594/WDCC/CLM_A1B_2_D3; 5) 10.15 94/WDCC/CLM_B1_1_D3; 6) 10.1594/WDCC/ CLM_B1_2_D3. 2009.

[30] Important user information on the regional climate simulation data with CLM (December 2008). Available from: http://www.mad. zmaw.de/fileadmin/extern/SGA-Fles/CLM_report_readme/clm_use r_information_dec_2008.pdf.

[31] Richter A, Adler GH, Fahrak M, Eckelmann W. Erläuterungen zur nutzungsdifferenzierten Bodenübersichtskarte der Bundesrepublik Deutschland im Maßstab 1:1 000000 (BÜK 1000 N, Version 2.3). Hannover 2007.

[32] Ahrends A, Penne C, Panferov O. Impact of target diameter harvesting on spatial and temporal pattern of drought risk in forest ecosystems under climate change conditions. Open Geogr J 2010; 3: 91-102.

[33] Federer CA, Vörösmarty C, Feketa B. Sensitivity of annual evaporation to soil and root properties in two models of contrasting complexity. J Hydrometeorol 2003; 4: 1276-90.

[34] Holst J, Holst T, Mayer H. Analyses of water balance components of beech stands in south-western Germany using BROOK90. Rep Meteor Inst Univ Freiburg 2008; vol. 17: pp. 61-8.

[35] Holst J, Rüdiger G, Offermann C, et al. Water fluxes within beech stands in complex terrain. Int J Biometeorol 2010; 54: 23-36.

[36] Armbruster M, Seegert J Feger KH. Effects of changes in tree species composition on water flow dynamics - Model applications and their limitations. Plant Soil 2004; 264: 13-24.

[37] Hammel K, Kennel M. Charakterisierung und Analyse der Wasserverfügbarkeit und des Wasserhaushalts von Waldstandorten in Bayern mit dem Simulationsmodell BROOK90, München: Heinrich Frank 2001; vol. 185.

[38] Müller J. Effects of drought on the water balance of selected forest sites and the evaluation of a drought risk. Schriften aus der Forstlichen Fakultät der Universität Göttingen und der Niedersächsischen Forstlichen Versuchsanstalt 2006; 142: 142-8.

[39] Schwärzel K, Häntzschel J, Grünwald T, Köstner B, Bernhofer C, Feger KH. Fundamentals of the spatially distributed simulation of the water balance of forest sites in a low-range mountain area. Adv Geosci 2007; 11: 43-7.

[40] Wellpott A, Imbry F, Schindler D, Mayer H. Simulation of drought for a Scots pine forest (Pinus sylvestris L.) in the southern upper Rhine plain. Meteorol Zt 2005; 14: 143-50.

[41] Achim A, Ruel JC, Gardiner BA. Evaluating the effect of precommercial thinning on the resistance of balsam fir to windthrow through experimentation, modeling, and development of simple indices. Can J For Res 2005; 35: 1844-53.

[42] Czajkowski T, Ahrends B, Bolte A. Critical limits of soil water availability (CL-SWA) in forest trees - an approach based on plant water status. vTI Agric For Res 2009; 59(2): 87-93.

[43] Blackwell PG, Rennolls K, Coutts MP. A root anchorage model for shallowly rooted Sitka spruce. Forestry 1990; 63: 73-91.

[44] Peltola H, Kellomaeki S, Vaeisaenen H, Ikonen VP. A mechanistic model for assessing the risk of wind and snow damage to single trees and stands of Scots pine, Norway spruce and birch. Can J For Res 1999; 29: 647-61.

[45] Nicoll BC, Gardiner BA, Rayner B, Peace AJ. Anchorage of coniferous trees in relation to species, soil type and rooting depth. Can J For Res 2006; 36: 1871-83.

[46] Stathers RJ, Rollerson TP, Mitchel SJ. Windthrow handbook for British columbia forests, B.C. Min. For., Victoria, B.C. Working Paper 9401 1994; p. 32.

[47] García-Santos G, Bruijnzeel LA, Dolman AJ. Modelling canopy conductance under wet and dry conditions in a sub-tropical cloud forest. Agric For Meteorol 2009; 149: 1565-72.

[48] Howard DM, Howard PJA. Relationships between $\mathrm{CO}_{2}$ evolution, moisture content and temperature for a range of soil types. Soil Biol Biochem 1993; 25(11): 1537-46. 
[49] Walse C, Berg B, Sverdrup H. Review and synthesis of experimental data on organic matter decomposition with respect to the effect of temperature, moisture, and acidity. Environ Res 1998; 6: $25-40$.

[50] Kamimura K, Kitagawa K, Saito S, Yazawa H, Kajikava T, Mizunaga H. Root anchorage under the combined condition of wind pressure and intensive rainfall: tree-pulling experiments with controlled soil water content. In: Mayer H, Schindler D, Eds. Proceedings of the $2^{\text {nd }}$ International Conference "Wind Effects on Trees" Ber. Met Inst. Freiburg 2009; vol. 19: pp. 149-54.

[51] Schelhaas MJ, Kramera K, Peltola H, van der Werf DC, Wijdeven SMJ. Introducing tree interactions in wind damage simulation. Ecol Model 2007; 207: 197-209.

(C) Panferov et al.; Licensee Bentham Open.

This is an open access article licensed under the terms of the Creative Commons Attribution Non-Commercial License (http://creativecommons.org/licenses/by$\mathrm{nc} / 3.0 /$ ) which permits unrestricted, non-commercial use, distribution and reproduction in any medium, provided the work is properly cited. 